\title{
O ethos discursivo na constituência lítero-musical da moda de viola $\mathrm{Mi}$ - lagre da vela
}

Cristiane da Silva FERREIRA

\section{Considerações iniciais}

Neste capítulo, concebemos o discurso da moda de viola, que converge com as práticas discursivas, sobretudo, do migrante rural, uma prática social, na medida em que revela as relações complexas nas quais o enunciador está inserido, ou seja, o seu posicionamento e sua identidade social. Propomos, então, explorar o ethos discursivo, um dispositivo de análise bastante produtivo que nos permite lançar um olhar singular ao discurso de moda viola Milagre da vela, produzido em 1959.

Considerando a dimensão intersemiótica do ethos discursivo, fundamentamo-nos nos estudos de Maingueneau (2011) e na 
Semiótica da Canção, desenvolvida por Tatit (2003, 2012), para responder à seguinte pergunta: em que medida o ethos discursivo, apreendido em sua dimensão intersemiótica, que compreende o componente linguístico e melódico, explicita na cenografia e no interdiscurso da moda de viola selecionada uma constituência lítero-musical?

Faremos, portanto, o seguinte percurso. Na primeira seção recuperamos, de modo breve, a origem da moda de viola e sua relevância na cultura brasileira. Na segunda seção, apresentamos as propostas da Semiótica da Canção de Tatit $(2003,2012)$ e as categorias de ethos discursivo e cenografia de Maingueneau (1997, 2008a, 2008b, 2008c, 2011). Na sequência, discorremos sobre a constituência literária e musical da moda de viola. Em seguida, propomos uma análise de sete recortes da moda de viola Milagre da vela, com o intuito de apreender os traços intersemióticos do ethos discursivo e, com efeito, responder à pergunta supracitada.

\section{A moda de viola no cancioneiro caipira}

Entoada ao som da viola por uma dupla de cantadores, a moda de viola, que se originou do Romanceiro Ibérico, configura-se em uma canção lírico-narrativa, cuja entoação melódica assemelha-se à melodia da fala cotidiana. Lima (1997), folclorista, musicista e propagador da cultura brasileira, explica que a melodia da moda de viola é lenta e o ritmo similar ao falar habitual, porque o interesse preferencial é a narrativa. O público, absorto neste universo, assume o papel de ouvinte para atentar-se ao que é "co-cantado".

A canção de moda de viola, que no início era acompanhada de coreografia, passou, nos bairros rurais, a ser executada por violeiros que tinham como público as pessoas da região que paravam para 
ouvir suas histórias cantadas. Comumente, essas modas de viola recebiam o nome de romance, pois segundo Sant'Anna (2000, p. 59), “[...] por sua fabulação novelesca e legendária, autênticas xácaras, ela é a que mais homologia apresenta com o Romanceiro".

A moda de viola era executada por duplas de cantadores masculinos, em duo de vozes terçadas, herança das modinhas portuguesas da segunda metade do século XVIII, conforme averiguou Nepomuceno (1999). Embora a indústria fonográfica, na atualidade, tenha incentivado a formação de duplas femininas, a formação original é a que predomina. $\mathrm{O}$ violeiro usa a viola de dez cordas ou cinco cordas dobradas para fazer o rasqueado nos intervalos da letra e pontear, de forma melódica, com um dedo tocando uma corda de cada vez, menciona Lima (1997).

Um violeiro que merece destaque por conceder maior projeção à moda de viola no país, principalmente na região Centro-Oeste e Sudeste, foi Tião Carreiro. Oriundo de Montes Claros, Minas Gerais, José Dias Nunes, o Tião Carreiro, ganhou destaque quando conheceu, em São Paulo, Teddy Vieira, que já tinha uma carreira consolidada como diretor e autor de letras de moda de viola, na década de 1950. Teddy Vieira apadrinhou Tião Carreiro concebendo-o como o principal intérprete das letras que compunha, entre elas o clássico Rei do Gado.

É notório que a consolidação da moda de viola na década de 1950 não constitui um fato apartado do sucesso de Tião Carreiro na capital paulista, pois ele foi um dos responsáveis pela propalação deste estilo musical. Corrêa (2000) constatou, inclusive, que muitos autores afamados confiavam a ele as letras de moda de viola que produziam, pois o sucesso era garantido. Além da voz grave, Tião Carreiro era conhecido por sua maneira peculiar de tocar viola. 
Por fim, reforçamos que não é por acaso que os violeiros recebem o reconhecimento do ouvinte, posto que ele é responsável por articular o poema à melodia para conceder vida à letra de moda de viola. Ao interagir com o público, o violeiro realiza uma performance que visa a despertar a atenção e a emoção do ouvinte. Hodiernamente, a moda de viola é ainda veiculada com intensidade na sociedade brasileira, sobretudo em regiões onde se disseminou a cultura do homem caipira, sendo passada de geração para geração.

\section{Semiótica da Canção, cenografia e ethos discursivo}

A teoria da Semiótica da Canção foi desenvolvida por Tatit (2012) após constatar que às canções populares, em comum, subjaz uma base de entonação análoga aos tonemas da fala, como se o cancionista ${ }^{48}$ estivesse instruindo quanto a um modo de dizer. Para apreender essa entonação, Tatit (2003) propôs um projeto de dicção do cancionista denominados de figurativização, passionalização e tematização. Cada um destes processos revela como o enunciador compatibiliza os elementos linguísticos e melódicos que se manifestam na sua maneira de dizer.

Assim, na figurativização, a melodia submete-se às inflexões da fala, pois a voz que fala se sobrepuja à voz que canta, criando efeitos de sentido de verdade enunciativa. Há, ainda, dois elementos que atuam no exame figurativo da melodia de qualquer canção: os dêiticos e os tonemas. O primeiro compreende os elementos linguísticos que indicam a situação enunciativa em que se encontra o enunciador. Os dêiticos presentificam a relação eu/tu (enunciador/co-enunciador) num aqui/agora, evidenciando a entonação

48 Tatit emprega o termo cancionista para designar não só o compositor, mas o intérprete também 
linguística que eclode no discurso da moda de viola. Com efeito, o co-enunciador é convidado a reviver as circunstâncias exibidas neste discurso.

Os tonemas são as terminações melódicas dos enunciados que se classificam em descendente, ascendente e suspensivo. A descendente exige uma inflexão de voz para o grave, que distende o esforço de emissão, propondo o repouso fisiológico e uma terminação asseverativa do conteúdo relatado. A ascendente é uma flexão de voz que busca a frequência aguda, exigindo o aumento do esforço final. Com isso, desponta a ideia de continuidade, de que algo ainda será dito. O suspensivo, que consiste na suspensão da altura, assim como a anterior, também sugere a continuidade, ou seja, aguarda-se resposta ou prorrogação das incertezas e tensões emotivas.

Na passionalização, o prolongamento das vogais e a ampliação da extensão da tessitura (distância entre a nota mais aguda e a mais grave) e dos saltos intervalares reduzem o andamento da canção, desvelando com nitidez cada contorno melódico. É o sentimento e as emoções do enunciador que são extrapolados na canção.

Na tematização, a redução da duração das vogais e o campo de utilização das frequências produzem uma progressão melódica mais veloz e mais segmentada pelos ataques consonantais, que ocasionam na redução do fluxo de informações. Conforme Tatit (2012), essa aceleração privilegia o ritmo e sua sintonia com o corpo, configurando-se em estilos musicais que mobilizam a ação.

Dito isto, conjecturamos que há, na constituição do ethos discursivo do enunciador/cancionista, traços musicais mobilizados pelas noções de figurativização, passionalização e tematização. Lembramos que os traços musicais fazem parte da noção de prática intersemiótica postulada por Maingueneau (2008a). Deste 
modo, como já faz parte dos estudos no campo do discurso na contemporaneidade, a dimensão semiótica não pode ser desconsiderada no processo de análise de textos multimodais (FERREIRA, FERREIRA, 2017).

Como destaca Tatit (2012), na fala, a voz humana estabelece linhas de inflexão sonora, as quais decorrem de variações de altura e intensidade dos sons emitidos. Tais variações, que resultam dos estados emocionais do enunciador e se projetam sobre a voz, são captadas também na melodia da canção. Desta forma, o modo de enunciação diz respeito à maneira de dizer do discurso. Este dizer, em nossa perspectiva, está intricado ao dizer melódico, isto é, à dimensão intersemiótica.

Reiteremos que, na Análise do Discurso, temos a vantagem de mobilizar noções advindas de outras disciplinas para captar a presença da materialidade melódica, uma vez que consideramos seu aspecto determinante na constituição do ethos. Uma noção bem-vinda diz respeito aos modos de enunciação no quadro de uma semântica global proposta por Maingueneau (2008a).

O modo de enunciação postulado por Maingueneau (2008a) sugere uma correspondência como gramática ritmo-melódica formulada por Tatit $(2003,2012)$. No caso deste último autor, o modo de enunciação pauta-se por alguns aspectos no quadro da oscilação temporal. O primeiro refere-se à concentração melódica a qual “[...] acusa a celeridade do continuum melódico e a moderação no uso do espaço de tessitura, como que destacando a importância da progressão horizontal" (TATIT, 2012, p. 50). O segundo diz respeito à expansão que, ao contrário da concentração, é regida pelo tempo num processo de contração/extensão, numa conformidade com o dizer do enunciador/cancionista. Ambas as categorias (concentração e expansão) afetam o regime melódico das canções. Desta articulação, consideramos a noção intersemiótica do ethos 
discursivo. Logo, como o ethos discursivo contribui para legitimidade do discurso, seu estatuto intersemiótico ressoa de modo significativo em uma "maneira de dizer".

Esta configuração musical permite-nos considerar a categoria de cenografia como "um processo de círculo paradoxal no qual a enunciação, por sua própria maneira de desdobrar seus conteúdos, deve legitimar a situação de enunciação que torna possível” (MAINGUENEAU, 1998, p. 21). Com isso, é possível mobilizar a oralidade entoada, própria da moda de viola e, por conseguinte, seu estatuto intersemiótico na construção do ethos discursivo.

No entanto, o ethos discursivo emerge da cenografia constituída na e pela enunciação. Trata-se de verificar que a cenografia, em nosso corpus de análise, vai sendo construída por meio da oralidade entoada na moda de viola, portanto, pelo agenciamento associativo entre letra e melodia. A categoria de cenografia, nos estudos de Maingueneau (1997, 2006, 2008b), é compreendida no quadro das cenas da enunciação. $\mathrm{O}$ autor ao constatar que "[...] um texto é na verdade o rastro de um discurso em que a fala é encenada” (MAINGUENEAU, 2006, p. 250), propõe o conceito de cenas. Com efeito, um texto não se resume a um conjunto de signos inertes dispostos simplesmente um ao lado do outro, isentos de qualquer propósito e estratégia. Apreendida no interior dos enunciados, a cena de enunciação relaciona-se, também, com os dêiticos, responsáveis pelas coordenadas pessoais, espaciais e temporais.

Maingueneau, assim, propõe três dimensões para as cenas da enunciação, quais sejam: a cena englobante, a cena genérica e cenografia. A cena englobante corresponde ao tipo de discurso, a cena genérica corresponde ao gênero de discurso, em nosso corpus de análise refere-se, respectivamente, ao discurso artístico e à moda de viola, e, por fim, a cenografia, que é instituída pelo próprio discurso (MAINGUENEAU, 2008b). 
Conforme enfatiza o autor, a cenografia não é um cenário pré-construído, determinado; é a própria enunciação que, à medida que se desenvolve, vai sendo construída. Configurando-se de forma dinâmica e criativa, ela acaba por englobar uma série de recursos linguístico-discursivos para que faça sentido e conquiste a adesão do co-enunciador a um determinado posicionamento. Ela, com efeito, está integrada ao ethos discursivo, participando, ambos, de um processo de enlaçamento que visa a validar a própria enunciação. Por isso, o ethos discursivo não pode ser tomado isoladamente.

O ethos discursivo é um processo interativo, que visa a levar o outro a se identificar, além de sua dimensão verbal, no sentido retórico, com um corpo investido de valores socialmente aceitos ou rechaçados. Como todo texto escrito ou oral é dotado de um tom, cuja função é dar autoridade ao que é dito, é por meio dele que o co-enunciador constrói uma representação do corpo do enunciador. A instância subjetiva que emerge no discurso passa a desempenhar o papel de fiador, imputando-lhe a responsabilidade do que é dito. Ao fiador, o enunciador atribui um caráter e uma corporalidade, cujo grau de precisão varia segundo os textos. $\mathrm{O}$ caráter contempla os traços psicológicos e a corporalidade refere-se não somente à constituição física do corpo, mas também a uma maneira de se vestir e de se movimentar na sociedade. O conceito de ethos proposto por Maingueneau (1997, 2001, 2006, 2011), portanto, vai além da dimensão verbal, pois cinge sobre uma concepção mais encarnada do ethos.

Ademais, julgamos relevante apontar que o ethos, inserido na perspectiva da $\mathrm{AD}$, não confere ao enunciador liberdade de escolha quanto ao seu papel desempenhado, pois ele está subordinado às coerções e restrições que são determinadas pelo seu posicionamento. 


\section{A constituência literária e musical da moda de vio- la}

Primeiramente convém definir que discursos constituintes são aqueles que tematizam sua própria constituição, pois se propõem como discursos de origem, validados por uma cena de enunciação que autoriza a si mesma. Detentores de um corpo de enunciadores consagrados, esses discursos cumprem a função de archéion, pois lhes confere um estatuto singular que os diferenciam dos demais discursos não-constituintes. Maingueneau (2009) apropriou-se desse termo grego, étimo latino archivum, para concebê-los como arquivo, tendo em vista que tais discursos elaboram uma memória discursiva.

Os discursos constituintes têm uma soberania sobre outros discursos, visto que os submetem ao seu sistema de restrição e conferem sentido aos atos da coletividade, instalando-se em sua memória discursiva. Vale frisar que a análise desses discursos não se reduz às grandes obras, visto que se caracterizam como uma produção discursiva heterogênea. Ao se materializarem, eles se convertem em múltiplos gêneros com um estatuto particular. Ainda que se instaure uma hierarquia entre os discursos, na realidade há uma interdependência entre eles, que contribui para consolidar a sua constituência.

Ligados por uma fonte legitimadora, os discursos constituintes são, ao mesmo tempo, auto e heteroconstituintes, pois ao se constituírem desempenham um papel constituinte para outros discursos. Investidos de autoridade, os enunciados desses discursos são concebidos como inscrições em uma rede institucional por suporem necessariamente um caráter exemplar, posto que seguem e dão exemplos. 
Tais enunciados só podem ser compreendidos no bojo do interdiscurso, onde há evidentemente uma variedade discursiva atuando sobre o discurso constituinte do qual eles fazem parte. Nos dizeres de Maingueneau (2009, p. 62),

há uma contínua relação entre discursos constituintes e não-constituintes, assim, como entre os discursos constituintes entre si. É, porém, da natureza destes últimos negar essa interação ou pretender submetê-las a seus princípios.

O texto da moda de viola possui traços de criação poética que confirmam seu pertencimento ao campo literário, mas pautarmo-nos somente pelo componente linguístico não é suficiente se, de fato, quisermos apreender essa prática discursiva de forma mais consistente, conforme Ferreira (2015). Certamente, há elementos de ordem musical atuando na liberação dos efeitos de sentido desse discurso, que clamam por reconhecimento.

O discurso da moda de viola é uma configuração que resulta da junção do campo discursivo literário e do campo discursivo musical. Por isso, ambos não podem ser apartados, uma vez que

uma letra cantada com uma certa melodia, é grande a riqueza de elementos que concorrem para os efeitos de sentido que ela pode produzir, sem falar nas inúmeras variáveis adicionais trazidas pelo arranjo ou pela interpretação de cada cantor. Tanto o componente linguístico quanto o melódico são portadores, cada qual, de muita informação que pode dizer substancialmente um bocado de coisas ao ouvinte (TATIT \& LOPES, 2008, p. 11). 
Assim, o discurso da moda de viola configura-se em narrativas versificadas e rimadas, que nos remetem ao causo, gênero de discurso bastante difundido na cultura do homem caipira. A cenografia também evoca uma instância enunciadora que transcende pela fala do enunciador, fazendo-o ocupar uma posição que oscila entre o mundo humano e as forças maiores. Esse funcionamento do discurso é uma forma de gerar o estatuto constituinte, à medida que a instância se coloca como detentora da verdade e de princípios morais.

Além disso, o discurso da moda de viola, ao trazer um universo que oscila entre o real e o imaginário, atribui sentidos aos atos compartilhados entre os membros da sociedade, ultrapassando os limites do tempo, de maneira a sedimentar uma existência atemporal. Desperta, a partir de então, um mundo que o valida por sua própria emergência, posto que o conteúdo torna-se inseparável da cenografia que lhe serve de suporte.

Outro aspecto a ser considerado é que as cenografias mobilizadas não são casuais, pois exprimem sua relação com a sociedade. A cenografia do causo é bastante propícia para identificarmos essa relação, pois o discurso se assenta sobre valores culturais e sociais do homem caipira, com o qual a instância enunciadora se identifica. É desse universo cultural que o co-enunciador é intimado a participar.

A cenografia reveste-se também de um código linguageiro, que deve estar em consonância com o posicionamento imposto, para gerar efeitos de sentido eficazes. Esse código não é neutro, isento de qualquer intencionalidade, pois legitima o discurso constituinte. O discurso da moda de viola investe-se de um código linguageiro informal, penetrado por marcas da oralidade, descumpridor das normas gramaticais, que melhor representa o enunciador e seu mundo, instaurado na cenografia. 
Vale destacar, ainda, que o código linguageiro não necessariamente consiste no código gráfico. A literatura também se vale da oralidade, que impõe um ritmo cadenciado pelo uso da voz, atingindo, com isso, "os registros sensoriais dos ouvintes para suscitar a comunhão" (MAINGUENEAU, 2009, p. 217). Considerando que o destino da letra, ou seja, a materialidade linguística da canção, é ser cantada, não há como ignorar o componente musical.

Nesse sentido, o discurso da moda de viola nutre-se de atos simbólicos, que são narrados de forma linear, tendo em vista um modelo de coerência que deve ser memorizado pelo público. $\mathrm{O}$ impacto que o discurso literário, seja ele escrito ou oral, terá sobre o co-enunciador envolve, portanto, a fusão da mensagem com o seu modo de organização discursiva. Trata-se, segundo Maingueneau (2009), de superar as oposições fundo e forma, texto e contexto, produção e recepção, cravadas pela análise textual.

Atrelado à cenografia e ao código linguageiro, eclode o ethos, por meio do qual conferimos a representação de um corpo investido de valores históricos e culturais. Identificamos esse corpo devido a uma maneira de dizer, que compreende os traços intersemióticos do ethos. É esse corpo em movimento, responsável por nos conduzir a uma dada conjuntura histórica, que convoca o co-enunciador a se identificar com seu posicionamento. A eficácia do discurso constituinte, bem como sua capacidade de conquistar a adesão reside, portanto, no ethos.

Precisamos considerar também a relação fincada entre o discurso lítero-musical e a memória, pois todo ato de posicionamento envolve um certo percurso de arquivo literário. No tocante a isso, o discurso que priorizamos nesse trabalho tem uma relação essencial com a memória, na medida em que compõe um arquivo da cultura do homem caipira. Isso revela que o discurso da moda de viola não consiste em uma prática isolada e alheia aos aconteci- 
mentos, pois é constituído pelas relações interdiscursivas que lhe confere uma identidade discursiva e o estatuto de arquivo.

O fato de ser encarado como arquivo revela que tal discurso compõe uma espécie de biblioteca imaginária, expressão cunhada por Maingueneau (2009), pois tem precedentes no enredo literário do Romanceiro Ibérico, conforme atesta Sant'Anna (2000). Evidentemente que a forma e, principalmente, o discurso da moda de viola foram ajustados e adaptados à cultura do homem caipira.

É desse arquivo, instalado na memória social, que o enunciador se serve para exercer seu processo de criação. Com efeito, o escritor do discurso da moda de viola tem de perambular por espaços e lugares que fomentem a sua imaginação, e não há lugar mais propício do que o contato direto com o povo, pois ele é simultaneamente o receptáculo e o propulsor de uma cultura.

\section{Milagre da vela: um causo entoado na viola}

O texto Milagre da vela, apreendido como discurso, tem como tema o retorno da alma de um pai à vida terrena para salvar os seus filhos de um incêndio, provocado em seu quarto por uma vela, acesa no dia em que seu falecimento completara um ano.

O título desse discurso acena para uma prática social sobrenatural e inexplicável, valorizada na cultura popular, que é a manifestação de milagres. Dessa maneira, o interdiscurso convoca o atravessamento do campo discursivo religioso, para interagir com o campo lítero-musical da moda de viola.

Tendo em vista essa interação, o discurso engendra a cenografia do causo, uma prática propícia para tratar de temas como milagres e assombrações, pressupondo um co-enunciador adepto a 
isso. A cenografia instalada implica nas coordenadas espaço-temporais, que articulam o enunciador e o co-enunciador, a cronografia e a topografia:

\section{Recorte 1}

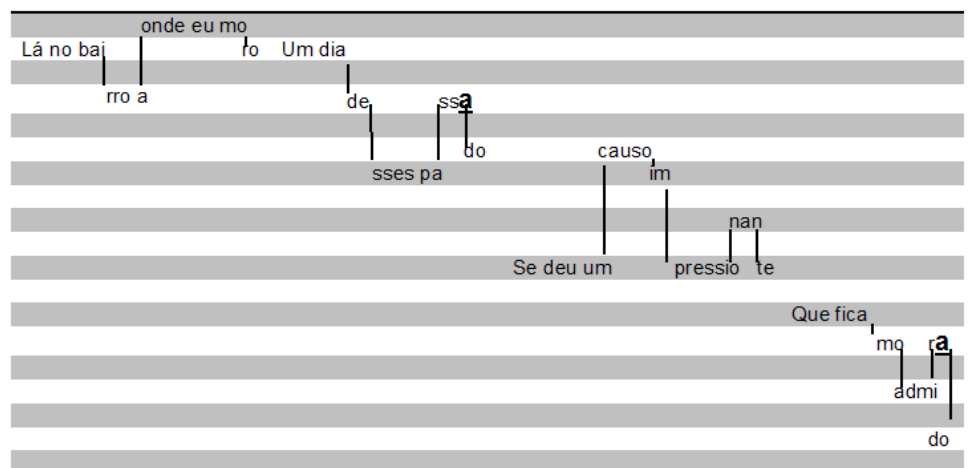

Com base no recorte, o enunciador determina para si e para o co-enunciador os lugares que esse tipo de enunciação exige para ser legítima: o enunciador assume o papel de contador de causo, enquanto o co-enunciador acata o papel de ouvinte. A topografia remete o co-enunciador ao bairro, local onde reside o enunciador, enquanto a cronografia compreende um passado não tão distante, que é referendado como Um dia desses passado.

O enunciador manifesta-se em primeira pessoa do singular, estabelecendo uma proximidade com o co-enunciador, de modo a despertar a sua sensibilidade. Para isso, o enunciador explora a inflexão de voz que, ao atingir as notas mais agudas, declina gradativamente, até atingir a nota mais grave do diagrama. É possível, então, depreendermos um ethos que se mostra surpreso, pois procura imprimir veracidade na enunciação, para interagir com o co-enunciador e conquistar sua atenção para o que vai ser "co-cantado". 
O componente melódico assegura esses efeitos de sentido, pois reproduz a entoação figurativizada, a qual evidencia a voz que fala sobre a voz que canta. Com efeito, a vocalidade gera um tom envolvente, de mistério e suspense, que acaba por envolver o co-enunciador na cenografia.

O item lexical impressionante, no enunciado Se deu um causo impressionante, revela o posicionamento do enunciador, ou seja, dos que aderem à prática de narrar causos. Assim, a cena enunciativa nos permite apreender o caráter de um sujeito conservador e receoso, visto que este acredita em causos. Por se tratar de uma prática discursiva típica do interior e da cultura do homem caipira, o causo concebe uma corporalidade simples e de idade mais avançada, que mantém em atividade a tradição de narrá-lo, mesmo inserida em um espaço urbano.

Também identificamos vestígios da passionalização, que consiste no alongamento da vogal e na desaceleração da melodia, no enunciado Um dia desses passado e Que ficamo admirado. A passionalização confere um tom dolente à cenografia, induzindo o co-enunciador a prenunciar a instalação de um drama.

O enunciador teatraliza a enunciação, de modo que o co-enunciador seja envolvido na cenografia. Para isso, explora o tonema descendente, que gera sentido de conclusão, dando a entender que o fato inesperado dominou o enunciador, de maneira que ele não tem mais palavras para pronunciar, como sugere o item lexical admirado.

Trata-se de uma estratégia discursiva que tem o objetivo de atrair a atenção do co-enunciador para a dinâmica do causo. Diante disso, reiteremos que, segundo Maingueneau (1997), o discurso é um sistema de restrições que regula uma atividade específica e uma forma de ação sobre o outro. 
A subjetividade do enunciador, a qual é inerente a toda linguagem, é captada não só na letra, mas, principalmente, na melodia do discurso. Vale a pena mencionar Tatit (2012), para o qual a letra de uma canção não precisa dizer tudo, pois certamente a melodia se encarregará de dizer o que falta.

O recorte a seguir comprova essa assertiva, pois a entonação melódica do enunciador reproduz o sentimentalismo que o acomete, evidenciando uma corporalidade que se mostra enternecida com o fato narrado. Conforme o desenho melódico, a figurativização é permeada pela passionalização, que promove o alongamento das vogais e, com efeito, a desaceleração da melodia, gerando uma vocalidade emotiva e enternecida com o causo:

\section{Recorte 2}

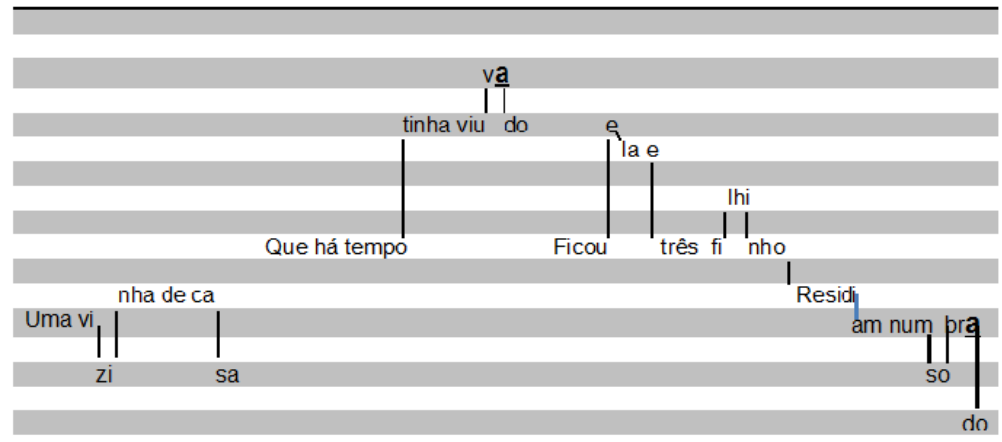

Notemos que o léxico viuvado, no enunciado Que há tempo tinha viuvado, atinge a nota mais aguda no diagrama, chamando a atenção para o posicionamento discursivo do enunciador, que se mostra um homem patriarcal. Basta ver que o enunciador evidencia que o velho concebeu um padrão de vida estável para a família, pois o léxico sobrado, no enunciado Residiam num sobrado, atesta um padrão de vida confortável, simbolizando a ascensão social 
da família. A passionalização, apreendida nos enunciados Que há tempo tinha viuvado e Residiam num sobrado, revela o estado emocional do enunciador, que lamenta profundamente a morte do velho, como revela o léxico ai, do enunciado $O$ velho quando morreu, $a i$, situado no recorte abaixo:

\section{Recorte 3}

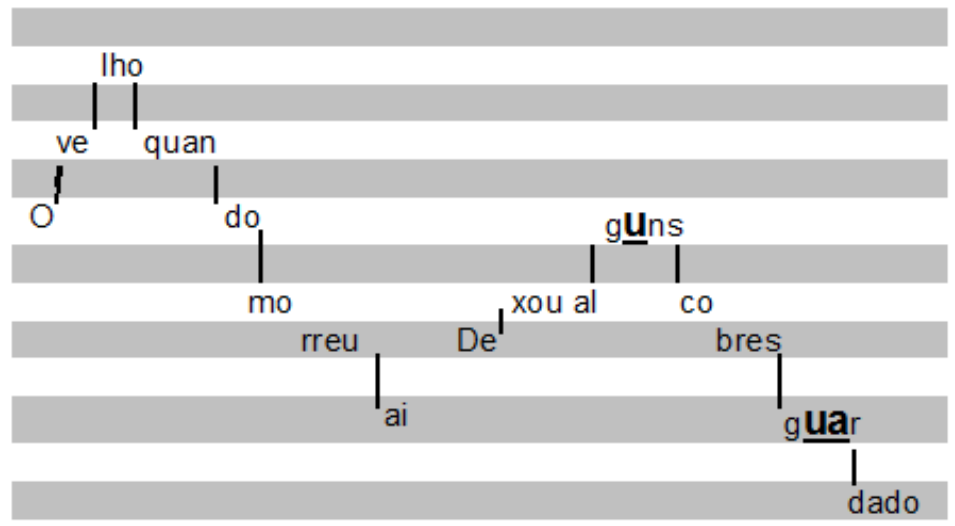

Ao revelar seu sentimento, o enunciador vai construindo laço de intimidade com o co-enunciador, de maneira a conquistar a sua confiança e, com efeito, a sua adesão para o respeito e gratidão com o pai. Além disso, a cenografia evidencia que o velho cumpriu, em vida, o papel de pai e marido, já que deixou alguns "cobres guardado".

O enunciador, portanto, coloca-se na cenografia como um defensor da família patriarcal, pois considera que o pai é o responsável pelo provimento econômico da esposa e dos filhos. Por isso, deve ser lembrado e cultuado, mesmo após a morte. A cenografia, 
então, faz emergir um ethos de indivíduo conservador, que propaga valores culturais por meio de práticas discursivas próprias de seu meio, como o causo. Julgamos que o homem caipira, ou mesmo o migrante rural, é o sujeito que representa esse estereótipo. Outro aspecto que reforça esse estereótipo é o atravessamento do discurso místico no interdiscurso:

\section{Recorte 4}

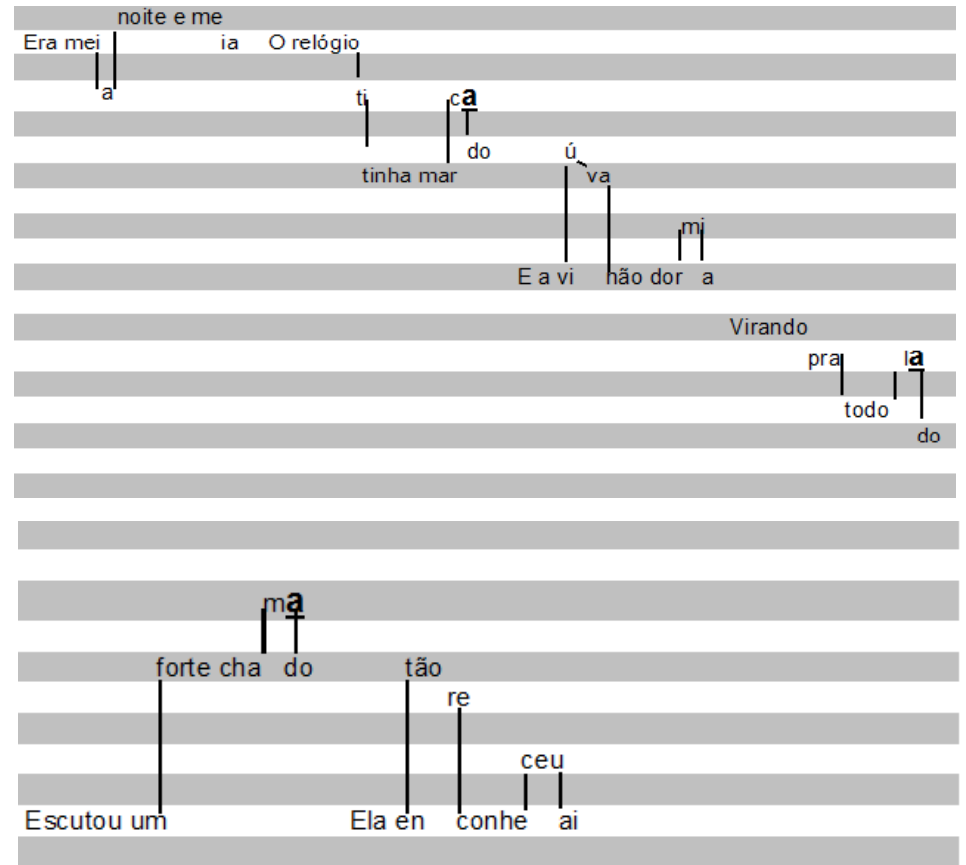

Que era a voz

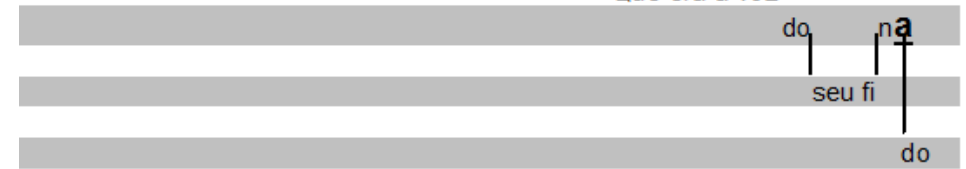


No enunciado Era meia noite e meia, a dêixis discursiva remete à cronografia da meia-noite e meia, pois a memória social a relaciona ao medo, ao suspense e ao mistério, provocando inquietação no co-enunciador. É nesse horário que o sobrenatural e o fantástico se manifestam, conforme sugerem os inúmeros contos e causos que recorrem a essa cronografia. A melodia também reforça esses efeitos de sentido, uma vez que a inflexão de voz atinge a nota mais aguda do diagrama, exigindo um esforço físico do enunciador, que desperta a atenção do co-enunciador.

A cronografia prenuncia a presença da "alma do outro mundo", bastante presente no imaginário popular, sobretudo nos causos. De acordo com Sant'Anna (2000), os temas relacionados a milagre e almas do outro mundo, além de serem difundidos na cultura do homem caipira, são também muito respeitados e temidos. Portanto, é notório que a cenografia insere uma cena validada na sociedade, tendo em vista evidenciar a pretensão heteroconstituinte desse discurso.

O tema intimida os sujeitos a perpetuarem, pela memória social, determinadas práticas discursivas valorizadas em seu meio, pois, do contrário, podem sofres punições. É nessa direção que a melodia atua, manifestando-se de forma coercitiva sobre o outro, já que ela se encarrega da dimensão vocal do ethos discursivo.

O enunciado Escutou um forte chamado/ Ela então reconheceu ai/ Que era a voz de seu finado reproduz um tom assombrado, que procura atemorizar o co-enunciador. É uma estratégia discursiva que confere efeitos de realidade ao discurso, constrangendo o co-enunciador a sentir o temor que o enunciador deseja que ele perceba. Por isso, a entoação melódica é importante, na medida em que incide diretamente sobre o discurso. 
Além disso, a análise que realizamos tem comprovado que a figurativização e a passionalização são processos melódicos atuantes na construção da imagem projetada no discurso, pois sustentam o tom imposto pelo discurso Milagre da vela.

Vale lembrar que o tom está associado a um caráter e a uma corporalidade, que recobrem a dimensão física e psíquica do ethos. É pela enunciação que o co-enunciador identifica essa corporalidade, que se assenta sobre valores conservadores, sedimentados na memória social, como revela o recorte na sequência:

\section{Recorte 5}

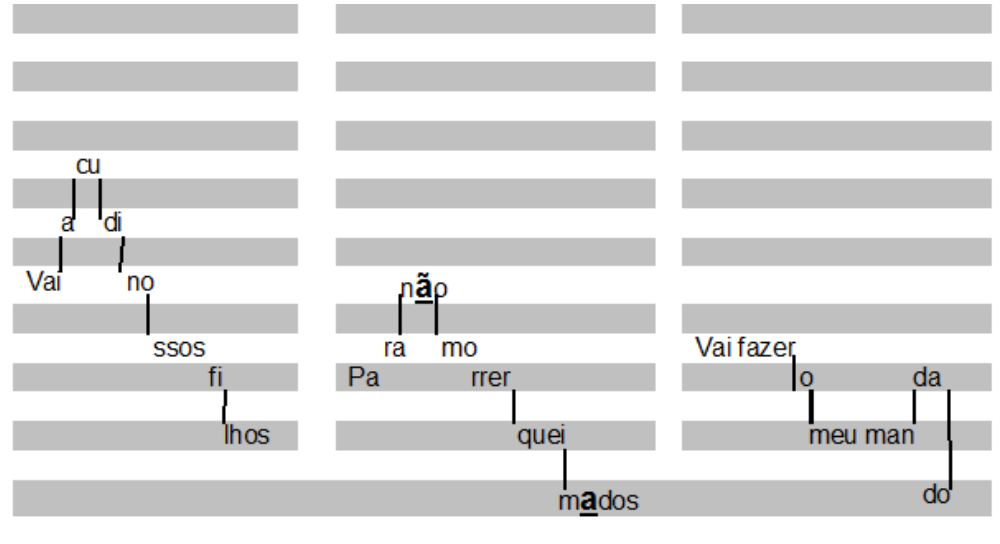

Ao reproduzir a fala do velho, o enunciador deseja que o co-enunciador perceba a importância de preservar a lembrança daquele que atuou como pai e marido, enquanto a mulher deve assumir o papel de submissão. Esses dizeres acionam a memória discursiva, que evoca a família patriarcal, fundamentada na autoridade paterna. 
Notemos que, mesmo sob a forma de assombração, o pai se faz presente para manter coesa a estrutura familiar. $\mathrm{O}$ enunciado Vai fazer o meu mandado revela a intenção do velho em reassumir o seu lugar, haja vista a expressão vai fazer, que indica ordem. Trata-se de uma cena que é validada na sociedade conservadora e machista.

Com efeito, o co-enunciador identifica uma corporalidade que adere a esse posicionamento discursivo. Estamos, portanto, diante de um ethos discursivo que deseja perenizar valores conservadores arraigados na memória discursiva popular, de modo a preservar a identidade social do migrante rural. Isso explica a constituência lítero-musical da moda de viola, a qual confere sentido aos atos da coletividade. Vamos ao recorte seguinte:

\section{Recorte 6}

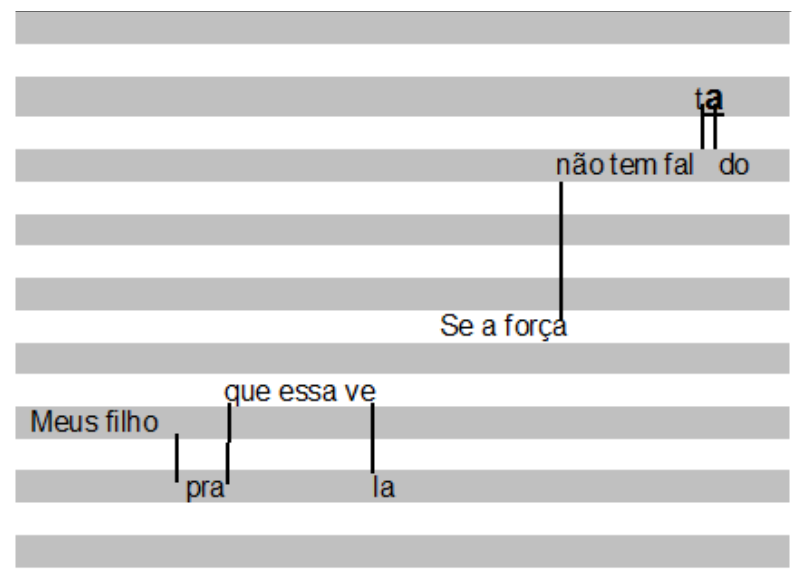

A cenografia se ancora em uma cena validada de forma negativa por aqueles que aderem a essa prática discursiva, pois a viúva 
não se lembra da morte do marido, como verificamos em pra que essa vela. $\mathrm{O}$ discurso insinua que a viúva deixou-se seduzir pelos bens materiais e pelo conforto da vida citadina, representado pelo item lexical força, no enunciado Se a força não tem faltado.

Enquanto o velho é mencionado na cena enunciativa como patriarca e protetor, a mulher é encarada como displicente e ingrata, já que o falecido a deixou em condições satisfatórias, como vimos nos enunciados Residiam num sobrado e Deixou alguns cobres guardado. $\mathrm{O}$ modo de dizer do enunciador atesta que ele adere ao posicionamento discursivo do homem conservador, induzindo o co-enunciador a rechaçar o posicionamento da viúva.

Dessa forma, o ethos que desvelamos se mostra machista e conservador, pois desaprova a mulher viúva, que não eternizou o luto. Em contrapartida, o comportamento dos filhos, no recorte seguinte, contrastam intencionalmente com o da mãe: 


\section{Recorte 7}

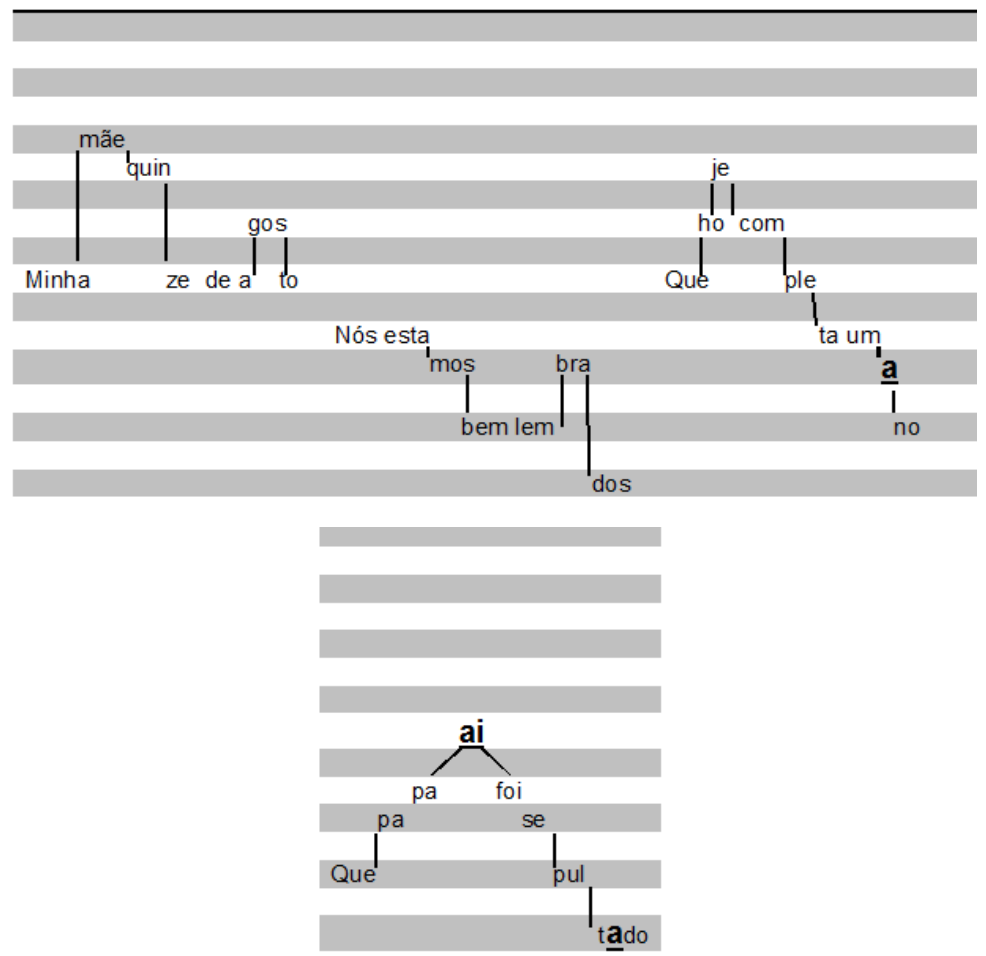

O enunciador investe na cenografia, utilizando cenas de fala validadas na cultura popular, como o gesto simbólico de acender vela ao finado, que indica o atravessamento do campo discursivo religioso no interdiscurso. A cenografia sedimenta a manutenção desta prática, por meio de uma vocalidade prudente e coercitiva, que leva o co-enunciador a afiançar o ethos discursivo de um sujeito moralizante e conservador.

O item lexical Nós, situado no enunciado Nós estamos bem lembrados, convoca o enunciador e o co-enunciador a se inserirem no causo, gerando efeitos de sentido de comprometimento com 
aquilo que se afirma. Nesse sentido, depreendemos um tom de advertência ao co-enunciador, visto que a memória discursiva tem papel fundamental na retomada e na propagação desses valores. A passionalização, que acarreta no prolongamento das vogais e na desaceleração da melodia, imprimi um tom dramático na cenografia, fazendo com que o co-enunciador possa refletir sobre o conteúdo do discurso.

Diante dessas considerações, constatamos que o discurso da moda de viola analisada revela, de fato, uma pretensão constituinte, já que se estabelece como um princípio regulador que dita quais valores e preceitos devem ser perpetuados na sociedade.

\section{Considerações finais}

Diante do que expusemos, o ethos discursivo da moda de viola Milagre da vela, produzida na década de 1959, em São Paulo, apreendido em sua dimensão intersemiótica, que compreende o componente linguístico e melódico, comprova a constituência lítero-musical desse discurso.

Pautados no projeto geral de dicção do cancionista, desenvolvido por Tatit (2012), verificamos que a letra e a melodia se coadunam na produção dos efeitos de sentido, devendo ser apreendidas simultaneamente. A entonação melódica induz o co-enunciador a sentir e vivenciar exatamente aquilo que o enunciador deseja que esse perceba.

É nítido que o enunciador, ao se investir de práticas identitárias da cultura popular, reivindica o ethos discursivo detentor de valores e princípios. Apreendidas no espaço de trocas enunciativas, denominado interdiscurso, essas práticas identitárias influen- 
ciam o comportamento social do co-enunciador, posto que estão alojadas em sua memória discursiva. Com efeito, estamos diante de um arquivo sociocultural e discursivo-musical da sociedade, e, sem dúvida, de um patrimônio imaterial da cultura brasileira.

\section{Referências}

CORRÊA, Roberto. A arte de pontear viola. 2.ed. Brasília: Edição do autor, 2000.

COSTA, Nelson Barros da. Música popular, linguagem e sociedade: analisando o discurso literomusical brasileiro. Curitiba: Apris, 2011.

FERREIRA, Cristiane da Silva. Ethos discursivo na constituência lítero-musical da moda de viola. São Paulo, SP. 2015. 257 f. (Doutorado em Língua Portuguesa) - Programa de Estudos Pós-Graduados em Língua Portuguesa, Pontifícia Universidade Católica de São Paulo, São Paulo, 2015.

FERREIRA. Cristiane da Silva \& FERREIRA, Anderson. Os traços intersemióticos do ethos discursivo na moda de viola Rosinha e Catimbau. Calidoscópio. Rio Grande do Sul, v. 15, n. 2, 2017, p. 362-374.

LIMA, Rossini Tavares de. Moda de viola - Poesia de circunstância. São Paulo: Dema, 1997.

MAINGUENEAU, Dominique. Novas tendências em Análise do Discurso. 3.ed. Campinas: Pontes \& UNICAMP, 1997.

. Termos-chave da análise do discurso. Belo Horizonte: Ed. UFMG, 1998.

. O contexto da obra literária. 3.ed. São Paulo: Martins Fontes, 2001. 
. Gênese dos discursos. São Paulo: Parábola, 2008a.

. Cenas da enunciação. São Paulo: Parábola, 2008b.

. A propósito do ethos. In: A. R., MOTTA e L., SALGADO (Orgs.). Ethos discursivo. São Paulo: Contexto, p. 11-32, 2008c. . Discurso Literário. 1.ed. São Paulo: Contexto, 2009. . Ethos, cenografia, incorporação. In., R., AMOSSY (org.) Imagens de si no discurso. A construção do ethos. São Paulo: Contexto, p. 69-90, 2011.

NEPOMUCENO, Rosa. Música caipira: da roça ao rodeio. 2.ed. São Paulo: 34, 1999.

SANT'ANNA, Romildo. A moda é viola: Ensaio do cantar caipira. Marília: UNIMAR, 2000.

TATIT, Luiz. Elementos para análise da canção popular. CASA, Cadernos de Semiótica Aplicada, 1(2), 7-21, 2003.

. O Cancionista: composição de canções no Brasil. 2.ed. São Paulo: Editora da Universidade de São Paulo, 2012. 